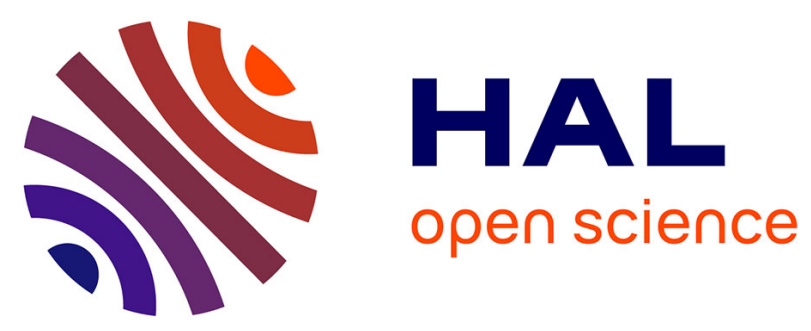

\title{
Rational Design of Enzyme-Modified Electrodes for Optimized Bioelectrocatalytic Activity
}

Lin Zhang, Cristina Carucci, Stéphane Reculusa, Bertrand Goudeau, Pauline Lefrançois, Sébastien Gounel, Nicolas Mano, Alexander Kuhn

\section{- To cite this version:}

Lin Zhang, Cristina Carucci, Stéphane Reculusa, Bertrand Goudeau, Pauline Lefrançois, et al.. Rational Design of Enzyme-Modified Electrodes for Optimized Bioelectrocatalytic Activity. ChemElectroChem, 2019, 6 (19), pp.4980-4984. 10.1002/celc.201901022 . hal-02302404

\section{HAL Id: hal-02302404 \\ https://hal.science/hal-02302404}

Submitted on 16 Mar 2020

HAL is a multi-disciplinary open access archive for the deposit and dissemination of scientific research documents, whether they are published or not. The documents may come from teaching and research institutions in France or abroad, or from public or private research centers.
L'archive ouverte pluridisciplinaire HAL, est destinée au dépôt et à la diffusion de documents scientifiques de niveau recherche, publiés ou non, émanant des établissements d'enseignement et de recherche français ou étrangers, des laboratoires publics ou privés. 
Rational Design of Enzyme Modified Electrodes for Optimized Bioelectrocatalytic Activity

Lin Zhang,a,b,§ Cristina Carucci,a,b,§ Stéphane Reculusa,a Bertrand Goudeau,a Pauline Lefrançois,a Sébastien Gounel,b Nicolas Manob*, Alexander Kuhna*

Dedication: This contribution is dedicated to Prof. Lo Gorton on the occasion of his 70th birthday in recognition of his outstanding contributions to the field of (bio)electrochemistry over several decades

Abstract: The immobilization of bilirubin oxidase (BOD) on macroporous gold electrodes for the optimization of bioelectrocatalytic activity is described. A bilirubin oxidase mutant S362C (cys-BOD) engineered with a cysteine residue located on purpose at the enzyme surface close to the T1 active center was used. It allows the attachment in one-step of a self-assembled monolayer of the enzyme to gold through a reaction between the thiol group of the cysteine residue and the metal surface. BOD immobilization of wild type and S362C mutant in macroporous gold electrodes allowed high retention of activity and perfect control of the overall BOD loading due to the fine-tuning of the macroporous structure. The macroporous arrangement together with the use of cys-BOD makes these rationally designed enzyme modified electrodes very promising candidates for highperformance bioelectrocatalytic devices with improved activity and stability.

Enzyme modified electrodes have been developed intensively in the last few decades as candidates for electroenzymatic devices such as biosensors or biofuel cells.[1-6] Their efficiency and performance depends on various interrelated factors including, and not limited, to the electrode surface/geometry, the nature of the enzyme and its immobilization.[6-7] Among different popular redox enzymes, bilirubin oxidase (BOD) is a multi-copper oxidase which has been widely used as an enzymatic catalyst for oxygen reduction with high selectivity, activity and stability at neutral $\mathrm{pH}$ and with a low overpotential.[8]

Several methods for the immobilization of BOD at electrode surfaces have been reported to achieve both, mediated and direct electron transfer (MET, DET) between the enzyme and the electrode.[3] For MET, the electrode exchanges electrons with the enzyme via a redox mediator, making it possible to have multiple layers of enzyme simultaneously connected with the electrode surface regardless of their orientation. However, the introduction of a redox mediator leads to an additional step in the electron transfer chain, which may decrease the open circuit potential for a biofuel cell system or limit the sensitivity for a biosensing system. Thus, enzyme modified electrodes capable to undergo $\mathrm{DET}$, where the electrons are directly transferred between the enzyme and the electrode, are sometimes preferable. To obtain an efficient direct electron transfer, the orientation of BOD needs to be controlled in such a way that the active center T1 is close to the electrode surface.[3] In the last decades, numerous strategies have been proposed to immobilize BOD on various electrodes allowing efficient DET.[7-14] To name a few, DET was achieved by BOD adsorption on electrodes functionalized with carboxyl groups,[15-17] or by pulse-assisted techniques.[18] In all these cases, the electron transfer between enzyme and electrode was facilitated compared to conventional adsorption, but in order to increase the stability of such an electroenzymatic device, it is preferable to immobilize BOD by using covalent binding.

Molecular engineering of enzymes by introducing individual amino acids is a straight-forward approach for facilitating covalent immobilization as long as the mutation is properly positioned on the enzyme structure. Taking advantage of the additional functions, the covalent bond formation uses the engineered site instead of the enzyme's natural surface groups, which are partially 
responsible for keeping its activity. Thus, there is less risk, at least to some extent, of losing activity upon immobilization. In addition, since the residue or tag is introduced at a fixed position on the surface of the enzyme, this might induce a preferential orientation of the enzymes. In the past, redox enzymes have been engineered with azide moieties,[19-20] histidine tags,[21-22] and cysteine tags[23-27] or residues[27] to react with corresponding surface terminal groups on the electrode. However in most of the cases, an electrode surface modification step is needed via the formation of self-assembled monolayers (SAMs) based on thiol derivatives[28-29] or by electrochemical reduction of diazonium salts.[30-31] The density of surface groups needs to be carefully controlled in order to avoid shielding of the electron transfer. Immobilization of enzymes on non-functionalized electrode surfaces therefore has several advantages as it is straight-forward and facilitates the electron transfer. NAD-dependent galactitol dehydrogenase has been engineered with three cysteine residues, and the tagged enzyme has been covalently immobilized on a gold electrode surface via thiol-gold interactions while maintaining almost full enzymatic activity.[23] However, no direct communication occurred between the enzyme and the electrode, as the NAD(H) cofactor freely diffuses in the solution and shuttles the electrons.

Besides engineering the molecular structure of the enzyme it is also important to precisely control the micro- and nanostructure of the electrode as this allows to fine-tune its active surface area and thus the global enzyme loading as well as the transport of substrate (eg. O2 for BOD).[32] Highly ordered macroporous gold electrodes, whose thickness and active surface area can be precisely controlled,[33] are a good choice for optimizing the performance of BOD modified electrodes. The macroporous electrodes are prepared by assembling silica beads on the electrode surface using the Langmuir-Blodgett technique and then infiltrate the silica template with gold by electrodeposition. The thickness of the macroporous gold can be precisely controlled during the filling process by following the associated periodic current oscillations (Figure S1).[34]

We reported earlier the use of a mutant BOD for the site directed immobilization of the enzyme through a 4-step coupling on gold electrodes.[35] In the present work, the same mutant, (cys-BOD), with a specifically located cysteine residue on the outer surface of the enzyme close to the T1 active center (Figure S2), was immobilized on a gold surface in only one step, allowing the formation of a layer of BOD and efficient DET. First, wild type-BOD (wt-BOD) and cys-BOD have been immobilized on electroplated gold wires for control purposes. We then designed porous cylindrical gold wires in order to increase the specific surface area and to maximize the enzyme loading and thus the current density.[36-37] Finally, both types of BOD are immobilized inside the highly ordered macroporous gold wire. The synergy between the enzyme and electrode material with fine-tuned porosity leads to an optimized bioelectrocatalytic activity which can be controlled in a very systematic way. Immobilization of cys-BOD in macroporous gold wires results in improved long term stability, retaining $75 \%$ of activity after 5 days of incubation, compared to only $20 \%$ for the wildtype. Furthermore, a very first proof of the actual cys-BOD distribution inside the electrode structure is provided by means of fluorescent labelling.

Immobilization of bilirubin oxidase mutant S362C and wildtype on electroplated gold wire

Electroplated gold wires were let to react overnight with cys-BOD or wt-BOD by dipping them into the respective $\mathrm{BOD}$ solutions. After washing, their electrocatalytic response with respect to oxygen 
reduction via DET was evaluated. Figure $1 \mathrm{~A}$ shows the cyclic voltammograms of cys-BOD (curve a) and wt-BOD (curve b) modified electrodes in an $\mathrm{O} 2$ saturated phosphate buffer solution $(0.1 \mathrm{M}, \mathrm{pH}$ 7.2 ) at $25^{\circ} \mathrm{C}$. When both forms of BOD are immobilized on smooth electroplated gold electrodes they show the same current response. Actually, one might expect a higher current for the mutant enzyme due to its preferential orientation. According to our ongoing studies this seems to depend on the exposed crystal facets, because for commercial pristine gold wires this is indeed what we observe. However, for the gold electrodeposits used in the present study those differences are within the error bars. Regarding the stability, wt-BOD retained $20 \%$ of its original activity at $+0.1 \mathrm{~V}$ vs $\mathrm{Ag} / \mathrm{AgCl}$ in $\mathrm{O} 2$ saturated $\mathrm{PB}$ solution $0.1 \mathrm{M} \mathrm{pH} 7.2$ after $19 \mathrm{~h}$ of continuous operation in chronoamperometry. In contrast, cys-BOD shows a better stability (Figure 1B) retaining up to $40 \%$ of its original activity under the same conditions. In order to ensure a higher enzyme loading and to amplify the current density in a controlled manner, the active surface area of the electrodes can be significantly increased by using a highly ordered macroporous structure as described in the following.
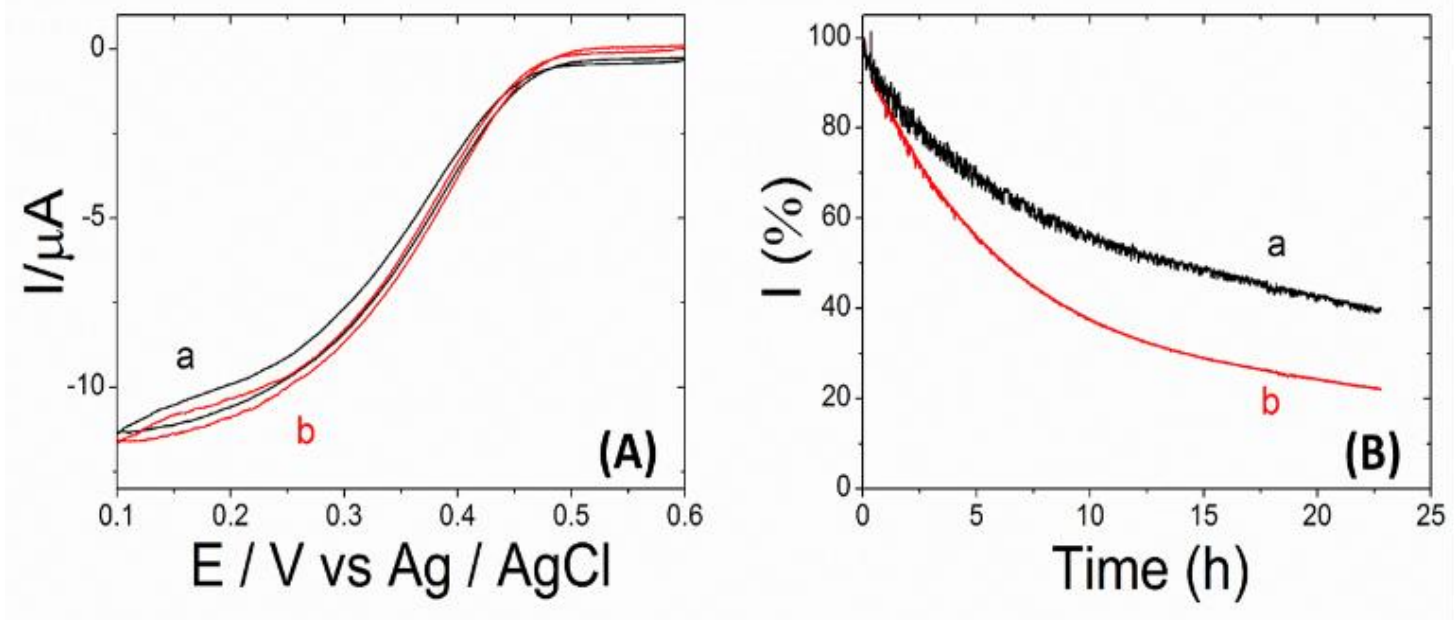

Figure 1. (A) Cyclic voltammograms recorded at $5 \mathrm{mV} / \mathrm{s}$ using (a) cys-BOD or (b) wild-type BOD modified electroplated gold wires in $\mathrm{O} 2$ saturated $\mathrm{PB}$ buffer $(0.1 \mathrm{M}, \mathrm{pH} 7.2)$ at $25^{\circ} \mathrm{C}$. (B) Amperometric response (\%) of (a) cys-BOD or (b) wild-type BOD modified electrodes in a $\mathrm{O} 2$ saturated $\mathrm{PB}$ buffer $(0.1 \mathrm{M}, \mathrm{pH} 7.2)$ at $25^{\circ} \mathrm{C}$ operating at $0.1 \mathrm{~V}$ vs. $\mathrm{Ag} / \mathrm{AgCl}$.

Characterization of macroporous gold electrodes

With the objective to increase in a very rational way the electroactive surface area, highly ordered macroporous gold electrodes were prepared. Macroporous layers with a pore size of $1170 \mathrm{~nm}$ and different thicknesses of 3, 7, 11 and 19 half layers $(\mathrm{HL})$ were generated on a gold wire $(\Phi=250 \mu \mathrm{m})$. Figure 2A illustrates the final hexagonal arrangement of the pores obtained after dissolution of the silica beads, which were serving as a template. The macropores are well-connected with each other, allowing substrate diffusion into the inner layers. The active surface area of $2 \mathrm{~cm}$ long gold wires with pore layers of different thicknesses has been characterized by cyclic voltammetry. As shown in Figure $2 \mathrm{~B}$, the gold oxide reduction peak located at $+0.95 \mathrm{~V}$ vs $\mathrm{Ag} / \mathrm{AgCl}$ increases with the number of porous layers. 

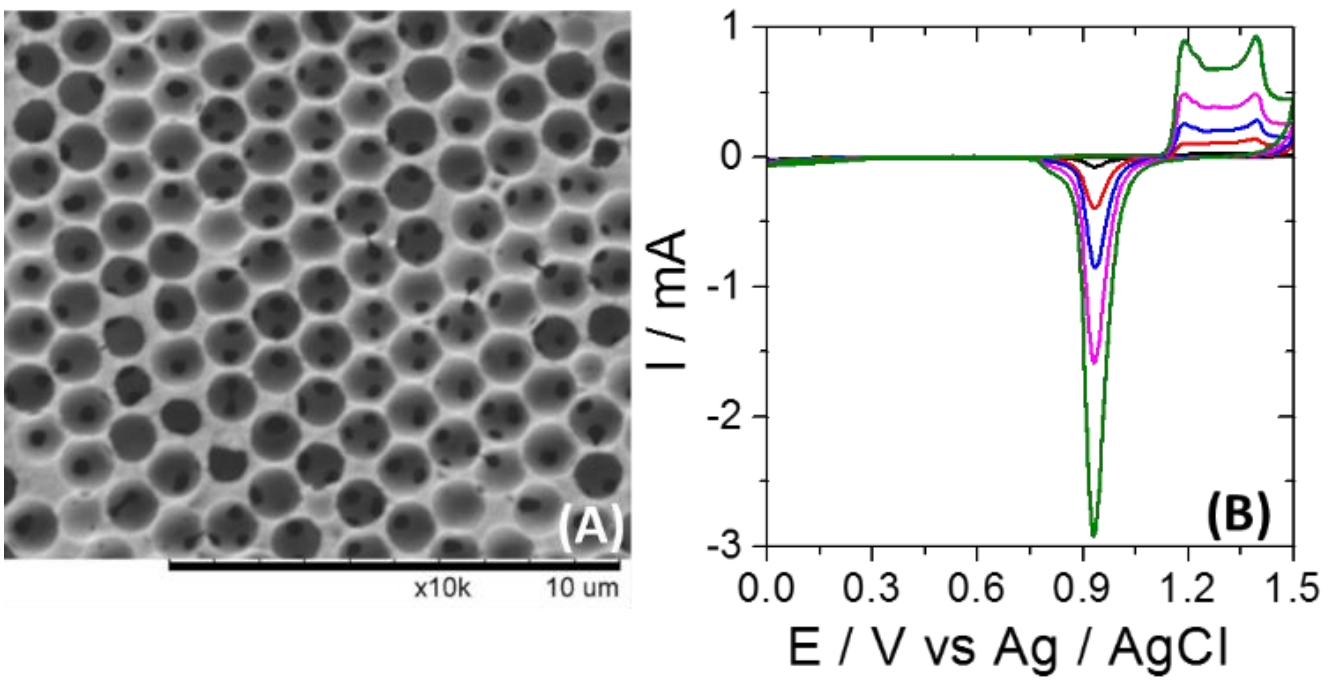

Figure 2. (A) Top view SEM image of a macroporous gold wire grown by electrochemical deposition through templates assembled from $1170 \mathrm{~nm}$ Si spheres. (B) Characterization of bare (black) and macroporous gold wires with $3 \mathrm{HL}($ red), $7 \mathrm{HL}$ (blue), $11 \mathrm{HL}$ (pink), and $19 \mathrm{HL}$ (green) by cyclic voltammetry in $0.1 \mathrm{M} \mathrm{H} 2 \mathrm{SO}$. The scan rate is $100 \mathrm{mV} / \mathrm{s}$. The length of all gold wires is $2 \mathrm{~cm}$.

The electroactive surface is calculated from the charge of the reduction peak $(S=Q / 390 \mathrm{mC} c \mathrm{~m}$ 2).[38] Plotting the active surface area versus the number of porous layers leads to a perfectly linear correlation. In order to verify that oxygen is able to penetrate these layers, first the non-catalyzed reduction of $\mathrm{O} 2$ was studied with porous structures of different thickness. As can be seen from Figure S3 the intensity of the $\mathrm{O} 2$ reduction correlates with the number of pore layers, confirming that the oxygen molecules are able to access also the inner pores through the connection windows. A slight plateau effect is observed for thicker electrodes, which can be understood by modeling the diffusional transport in such electrodes.[32]

Immobilization of BODs on macroporous electrodes

The engineered cys-BOD was then immobilized in macroporous gold electrodes with different thickness following the same immobilization strategy as for the flat wire. As during the immobilization process, cys-BOD needs to pass through several connection windows (black spots in Figure $2 \mathrm{~A}$ ) before reaching the bottom part of the porous layer, it is necessary to check whether the enzyme is uniformly distributed. Alexa 488 fluorescent dye has been used as a label for cys-BOD by coupling it to the surface amino groups of the enzyme. After immobilizing the labeled enzyme, its distribution in the cross section of the electrode was studied by confocal fluorescence microscopy for the first time. Figure $3 \mathrm{~A}$ shows the image of a $11 \mathrm{HL}$ macroporous gold electrode modified with labeled cys-BOD. A well-defined fluorescent layer is observed, having a thickness of around $6 \mu \mathrm{m}$, in very good agreement with the theoretical thickness of 11 half layers $(6.4 \mu \mathrm{m})$, thus indicating that the whole internal space of the macroporous layer is modified with enzyme. In the zoom, one can even recognize the regular arrangement of the macropores. Therefore, the global enzyme loading 
should be proportional to the active surface area. Despite the wide use of porous materials for enzyme immobilization, this is the first example and direct evidence that porous electrodes can be fully perfused with enzymes. Figure 3 illustrates the bioelectrocatalytic performance of cys-BOD (B) and wildtype (C) modified macroporous electrodes with increasing thickness in an oxygen saturated phosphate buffer $(\mathrm{pH} 7.2)$ at $25^{\circ} \mathrm{C}$. Plotting the catalytic current at $+0.1 \mathrm{~V}$ vs $\mathrm{Ag} / \mathrm{AgCl}$ versus the number of half layers, a linear increase of catalytic current up to $11 \mathrm{HL}$ is observed. For even thicker electrodes, the current slowly starts to saturate and eventually reaches a plateau. This can be explained by a competition between the electroenzymatic $\mathrm{O} 2$ consumption, governed by the kinetics of the immobilized enzymes, and $\mathrm{O} 2$ supply, limited by diffusion through the porous structure. In the case of 19HL, 02 diffusion is becoming the limiting factor, leading to a saturation in catalytic current. Despite these transport limitations, the controlled design of the electrode's microstructure allows increasing the catalytic current by more than one order of magnitude.

We have verified the presence of a covalent bond between cys-BOD and the Au electrode by electroreductive desorption. As it is well-known that a SAM of molecules on gold can be removed by electroreduction at negative potentials,[32-39] we triggered the progressive breaking of the thiol-Au bonds by potential cycles down to $-1.5 \mathrm{~V}$. The remaining amount of enzyme is characterized by their electrocatalytic activity in $\mathrm{O} 2$ saturated buffer (Figure 4A). After one reduction cycle, half of the electrocatalytic current is lost, indicating that half of the immobilized cys-BOD has been removed from the electrode surface. After five reduction cycles, almost no electrocatalytic response is left, indicating a complete electrodesorption of cys-BOD. 

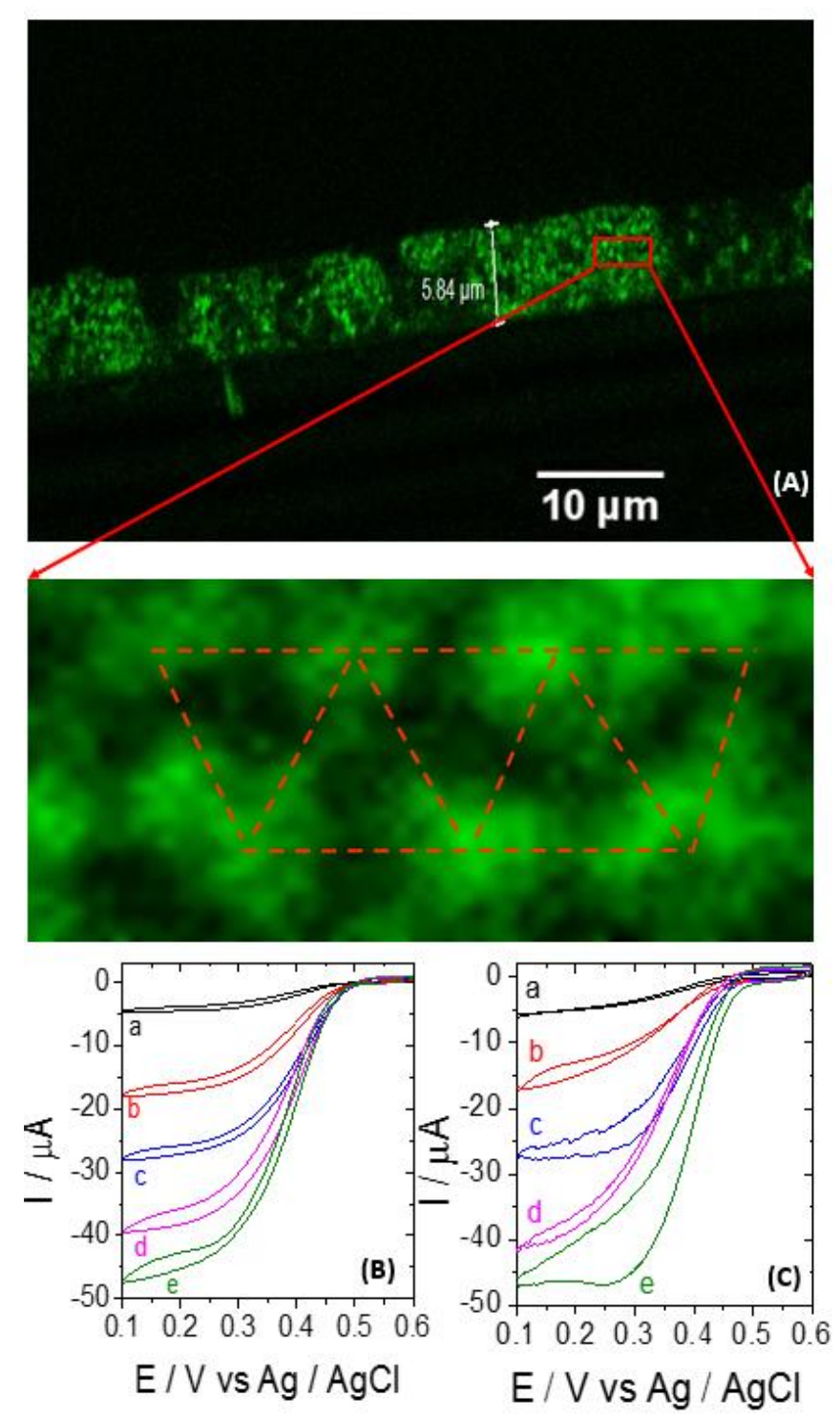

Figure 3. (A) Cross-section image of a macroporous electrode with 11 half layers modified with Alexa 488 labeled cys-BOD recorded by confocal fluorescence spectroscopy. (B) Cyclic voltammograms with a potential scan rate of $5 \mathrm{mV} / \mathrm{s}$ using cys-BOD modified bare (a) and macroporous gold wires with $3 \mathrm{HL}(\mathrm{b}), 7 \mathrm{HL}$ (c), $11 \mathrm{HL}$ (d), and $19 \mathrm{HL}$ (e) in 02 saturated phosphate buffer $(0.1 \mathrm{M}, \mathrm{pH} 7.2)$ at $25^{\circ} \mathrm{C}$. (C) Cyclic voltammograms with a potential scan rate of $5 \mathrm{mV} / \mathrm{s}$ using wt-BOD modified bare (a) and macroporous gold wires with $3 \mathrm{HL}(\mathrm{b}), 7 \mathrm{HL}(\mathrm{c}), 11 \mathrm{HL}(\mathrm{d})$, and $19 \mathrm{HL}(\mathrm{e})$ in $\mathrm{O} 2$ saturated phosphate buffer $(0.1 \mathrm{M}, \mathrm{pH} 7.2)$ at $25^{\circ} \mathrm{C}$.

Stability of cys-BOD modified electrode

Since the stability of an enzyme modified electrode is one of the key issue in electroenzymatic devices, it is important to examine this aspect. Thus the long-term stability of the modified electrodes in buffer solution was also evaluated. A wt-BOD-Au and a cys-BOD-Au electrode were incubated in phosphate buffer $(0.1 \mathrm{M}, \mathrm{pH} 7.2)$ at $4^{\circ} \mathrm{C}$ and their stability was characterized via the electrocatalytic response to $\mathrm{O} 2$. wt-BOD-Au shows a $80 \%$ decrease of activity after 5 days incubation (Figure 4B). The loss in current likely arises from spontaneous desorption of the enzyme from the 
electrode. This behavior is in strong contrast to what has been observed for cys-BOD-Au (Figure 4C). Only $25 \%$ of the catalytic current was lost after 5 days, indicating that the electrode is much more stable with respect to long-term incubation.
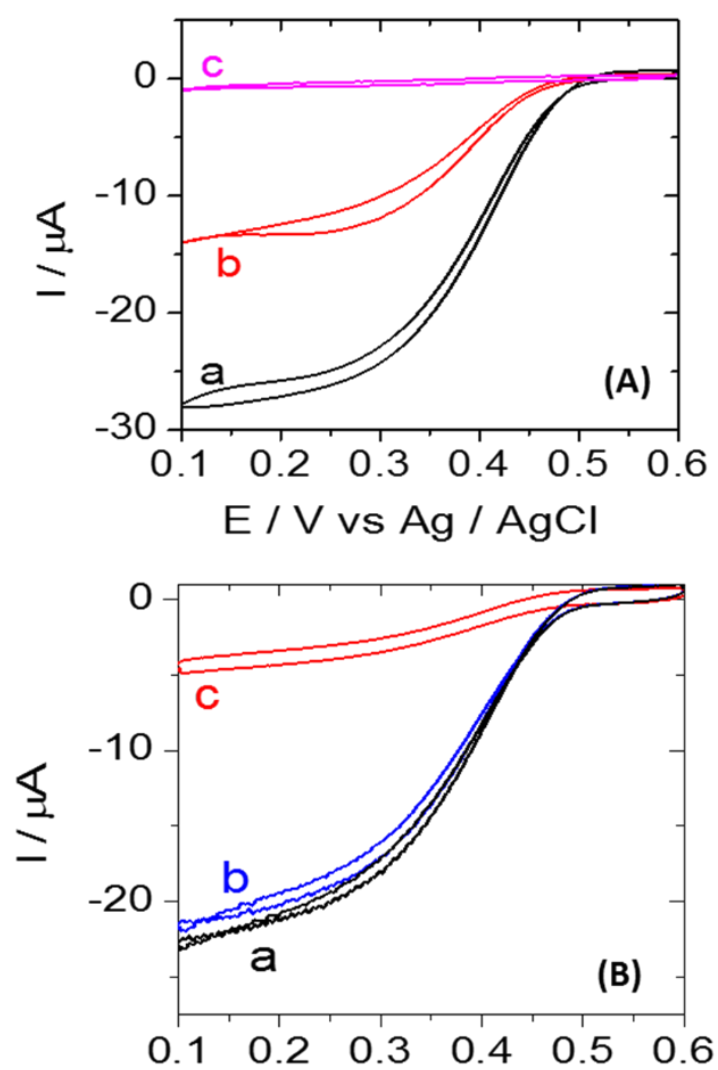

$\mathrm{E} / \mathrm{V}$ vs $\mathrm{Ag} / \mathrm{AgCl}$

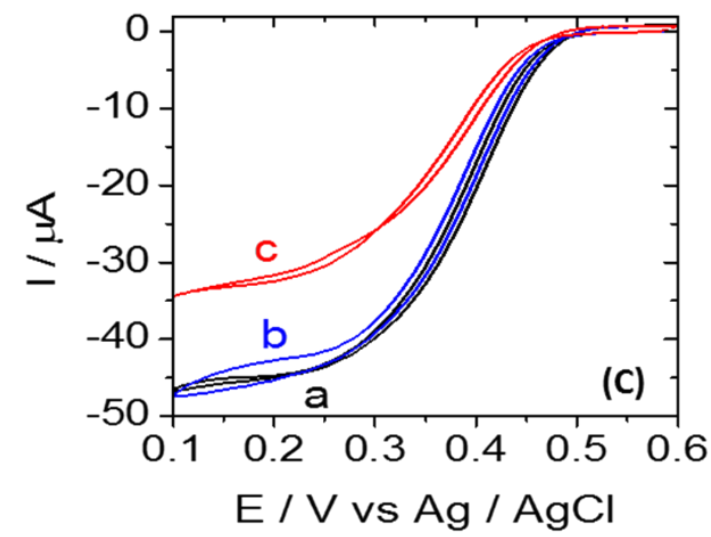

Figure 4.(A) Cyclic voltammograms with a cys-BOD-7HL-Au electrode in $\mathrm{O} 2$ saturated phosphate buffer (0.1 M, pH 7.2) before (a) and after running 1 (b) and 5 (c) reduction cycles to $-1.5 \mathrm{~V}$ vs. $\mathrm{Ag} / \mathrm{AgCl}$. (B) Cyclic voltammograms recorded at a potential scan rate of $5 \mathrm{mV} / \mathrm{s}$ using a wt-BOD-7HLAu electrode in $\mathrm{O} 2$ saturated phosphate buffer $(0.1 \mathrm{M}, \mathrm{pH} 7.2)$ after incubation at $4^{\circ} \mathrm{C}$ for (a) 0 , (b) 1 , and (c) 5 days. (C) Cyclic voltammograms recorded at a potential scan rate of $5 \mathrm{mV} / \mathrm{s}$ using cys-BOD$19 \mathrm{HL}$-Au electrode in $\mathrm{O} 2$ saturated phosphate buffer (0.1 M, pH 7.2) after incubation at $4^{\circ} \mathrm{C}$ for (a) 0 , (b) 1 , and (c) 5 days. 
This increased long-term stability of cys-BOD-Au is interpreted as the consequence of the covalent bond between the enzyme and the gold structure, thus avoiding enzyme leaching even after several days of incubation.

\section{Conclusions}

We developed a rational strategy to enhance the bioelectrocatalytic current of bilirubin oxidase on gold electrodes and its stability. First, a cysteine residue was introduced by molecular engineering at the outer surface of bilirubin oxidase close to the T1 active center in order to favor covalent interactions between the enzyme and the gold electrode. Then, highly ordered macroporous gold wires were designed with an increasing active surface area which is proportional to the number of porous layers. Finally, cys-BOD was homogeneously chemisorbed throughout the entire macroporous structure, monitored by confocal fluorescence microscopy. This allows fine-tuning the enzyme loading per geometric surface area. The electrocatalytic response of macroporous cys/wt-BOD-Au electrodes with respect to $\mathrm{O} 2$ reduction by DET increases linearly with the number of porous half layers up to $11 \mathrm{HL}$. A saturation of catalytic current was observed for thicker porous electrodes due to $\mathrm{O} 2$ mass transport limitations. Both enzymes show the same tendency, however the long term stability can be significantly improved when the mutant cys-BOD is employed, thus demonstrating that its use together with macroporous gold wires leads to bioelectrocatalytic performances that are not achievable with non-optimized devices.

Experimental Section

Experimental Details of the work can be found in SI.

Acknowledgements

This study has received financial support from the project BIO3 (ANR-16-CE19-0001-03). The work was also supported by the Laboratory of Excellence AMADEus with the reference ANR-10-LABX-0042AMADEUS, and has benefitted from aid by the state operated "Agence Nationale de la Recherche" under the program "Initiative for Excellence IdEx Bordeaux" holding the reference ANR-10-IDEX0003-02. A.K. acknowledges financial support from the Institut Universitaire de France.

Keywords: Bilirubin oxidase $\bullet$ Cysteine $\bullet$ Enzyme engineering $\bullet$ Direct electron transfer $\bullet$ Macroporous electrodes• Bioelectrocatalysis

\section{References}

[1] T. Bobrowski, W. Schuhmann, Curr. Opin. Electrochem. 2018, 10, 112-119.

[2] M. Gamella, A. Koushanpour, E. Katz, Bioelectrochem. 2018, 119, 33-42.

[3] N. Mano, A. de Poulpiquet, Chem. Rev. 2018, 118, 5, 2392-2468.

[4] P. Bollella, L. Gorton, Curr. Opin. Electrochem. 2018, 10, 157-173.

[5] S. Shleev, ChemPlusChem 2017, 82, 4, 522-539.

[6] M. Rasmussen, S. Abdellaoui, S.D. Minteer, Biosens. Bioelectron 2016, 76, 91-102.

[7] Y. Takahashi, M. Wanibuchi, Y. Kitazumi, O. Shirai, K. Kano, J. Electroanal. Chem. 2019, 843, 47-53.

[8] V.P. Hitaishi, I. Mazurenko, M. Harb, R. Clément, M. Taris, S. Castano, D. Duché, S. Lecomte, M. Ilbert, A. de Poulpiquet, E. Lojou, ACS Catal. 2018, 8, 12, 12004-12014. 
[9] D. Takimoto, S. Tsujimura, Chem. Lett. 2018, 47, 10, 1269-1271.

[10] S. Gentil, M. Carrière, S. Cosnier, S. Gounel, N. Mano, A. Le Goff, Chem. Eur. J. 2018, 24, 33, 8404-8408.

[11] H.-q. Xia, Y. Kitazumi, O. Shirai, K. Kano, Anal. Sci. 2017, 33, 7, 839-844.

[12] L. dos Santos, V. Climent, C.F. Blanford, F.A. Armstrong, Phys. Chem. Chem. Phys. 2010, 12, 42, 13962-13974.

[13] X. Xiao, T. Siepenkoetter, P.Ó. Conghaile, D. Leech, E. Magner, ACS Appl. Mater. Interfaces 2018, $10,8,7107-7116$.

[14] V. Wernert, C. Lebouin, V. Benoit, R. Gadiou, A. de Poulpiquet, E. Lojou, R. Denoyel, Electrochim. Acta 2018, 283, 88-96.

[15] I. Mazurenko, K. Monsalve, J. Rouhana, P. Parent, C. Laffon, A.L. Goff, S. Szunerits, R. Boukherroub, M.-T. Giudici-Orticoni, N. Mano, E. Lojou, ACS Appl. Mater. Interfaces 2016, 8, 35, 23074-23085.

[16] T. Siepenkoetter, U. Salaj-Kosla, X. Xiao, P.Ó. Conghaile, M. Pita, R. Ludwig, E. Magner, ChemPlusChem 2017, 82, 4, 553-560.

[17] K. Murata, K. Kajiya, N. Nakamura, H. Ohno, Energy Environ. Sci. 2009, 2, 12, 1280-1285.

[18] F. Lopez, T. Siepenkoetter, X. Xiao, E. Magner, W. Schuhmann, U. Salaj-Kosla, J. Electroanal. Chem. 2018, 812, 194-198.

[19] J. Kalia, R.T. Raines ChemBioChem 2006, 7, 9, 1375-1383.

[20] J. Kalia, N.L. Abbott, R.T. Raines, Bioconjugate Chem. 2007, 18, 4, 1064-1069.

[21] Y.-C. Lin, M.-R. Liang, Y.-C. Lin, C.-T. Chen, Chem.: Eur. J 2011, 17, 46, 13059-13067.

[22] E.E. Ferapontova, V.G. Grigorenko, A.M. Egorov, T. Börchers, T. Ruzgas, L. Gorton, Biosens. Bioelectron. 2001, 16, 3, 147-157.

[23] P. Kornberger, J. Gajdzik, H. Natter, G. Wenz, F. Giffhorn, G.W. Kohring, R. Hempelmann, Langmuir 2009, 25, 20, 12380-12386.

[24] L. Zhang, N. Vilà, T. Klein, G.-W. Kohring, I. Mazurenko, A. Walcarius, M. Etienne, ACS Appl. Mater. Interfaces 2016, 8, 27, 17591-17598.

[25] V. Pardo-Yissar, E. Katz, I. Willner, A.B. Kotlyar, C. Sanders, H. Lill, Faraday Discussions 2000, 116, $0,119-134$

[26] E. Ferapontova, K. Schmengler, T. Börchers, T. Ruzgas, L. Gorton, Biosens. Bioelectron. 2002, 17, $11,953-963$.

[27] F.A. Al-Lolage, M. Meneghello, S. Ma, R. Ludwig, P.N. Bartlett, ChemElectroChem 2017, 4, 6, 1528-1534.

[28] D.F. Yang, C.P. Wilde, M. Morin, Langmuir 1996, 12, 26, 6570-6577.

[29] C.D. Bain, J. Am. Chem. Soc. 1989, 111, 1, 321-335.

[30] J. Lyskawa, D. Bélanger, Chem. Mater. 2006, 18, 20, 4755-4763. 
[31] M.-C. Bernard, A. Chaussé, E. Cabet-Deliry, M.M. Chehimi, J. Pinson, F. Podvorica, C. Vautrin-UI, Chem. Mater. 2003, 15, 18, 3450-3462.

[32] T.D. Le, L. Zhang, S. Reculusa, G. Vignoles, N. Mano, A. Kuhn, D. Lasseux, ChemElectroChem $2019,6,1,173-180$.

[33] S. Reculusa, M. Heim, F. Gao, N. Mano, S. Ravaine, A. Kuhn, Adv. Funct. Mater. 2011, 21, 4, 691698.

[34] A. Kuhn, M. Heim, Highly Ordered Macroporous Electrodes. In Springer Handbook of Electrochemical Energy, Eds. Springer Berlin Heidelberg: Berlin, Heidelberg, 2017; pp 143-206.

[35] F.A. Al-Lolage, P.N. Bartlett, S. Gounel, P. Staigre, N. Mano, ACS Catal. 2019, 9, 3, 2068-2078.

[36] A. Karajić, S. Reculusa, M. Heim, P. Garrigue, S. Ravaine, N. Mano, A. Kuhn, Adv. Mater. Interfaces 2015, 2, 12, 1500192.

[37] A. Karajić, S. Reculusa, S. Ravaine, N. Mano, A. Kuhn, ChemElectroChem 2016, 3, 12, 2031-2035.

[38] S. Trasatti, O.A. Petrii, J. Electroanal. Chem. 1992, 327, 1, 353-376.

[39] C.A. Widrig, C. Chung, M.D. Porter, J Electroanal. Chem. Interfacial. Electrochem. 1991, 310, 1, 335-359. 